\title{
Lawet dance and ebleg dance: the term analysis towards its movement qualities
}

\author{
${ }^{\otimes}$ Djarot Heru Santosa, Gardenia Kartika Dewi, Aprina Dwi Rahayu
}

Faculty of Cultural Science, Universitas Gajah Mada, Yogyakarta, Indonesia

Received: November 11, 2016. Revised: January 23, 2017. Accepted: April 2, 2017

\begin{abstract}
This study offers an insight of a research activity which focuses on art analysis, but lies its concern from the perspective of linguistics. This study is aiming at analyzing linguistic data that are related to traditional art activity to obtain further understanding beyond the existence of the art itself. Example of the activity is the linguistic analysis of terms used to label the kinds or qualities of dance movement from Central Java province, in this case are Lawet dance and Ebleg dance. Kebumen, as one of regency in Central Java, is chosen as the research location since it owns rich of typical traditional arts (local), both from the perspective of the art forms as well as the linguistic aspects. This research is analyzed by employing linguistic theory, especially the analysis of morphology and semantic. Implication of linguistic analysis done to the terms is a deep understanding towards the traditional dances being analyzed. It is further resulted in the form of identity affirmation to the traditional arts exist in the society's environment.
\end{abstract}

Keywords: term analysis; movement qualities; Lawet dance; Ebleg dance

How to Cite: Santosa, D. H., Dewi, G. K., \& Rahayu, A. D. (2017). Lawet dance and ebleg dance: the term analysis towards its movement qualities. Harmonia: Journal of Arts Research And Education, 17(1), 31-40. doi:http://dx.doi.org/10.15294/ harmonia.v17i1.7805

\section{Introduction}

Indonesian culture consists of variations of many local cultures. This diversity does not only generate differences and variations but also may enrich and strengthen the national culture. Ethnic group is a group of people which are bound by consciousness in sharing identity to keep togetherness alive. According to Koentjaraningrat (1990, p. 264), the similarities may comprise of ideas, ways of thinking, conceptualization systems, and meanings which underlie the way of living of society. This awareness will trigger a typical form of ethnicity which will later call as identity.

The local wisdom or local genius is a set of knowledge arise in a certain group or community, either originated from the past generation or originated from an experience that is related to other environments and communities to solve problems and challenges that are being faced. Djawanai (2011) states that to dig and to search for local wisdom in order to reveal the identity awareness, one can review the development paradigm that initiates top down policy-which means the government knows best what a community needs. Further, society empowerment is also needed to explore potentials and abilities had by the society.

The main material object in this study is the existence of a variety of traditio-

\footnotetext{
${ }^{\boxplus}$ Corresponding author: Bulaksumur, Caturtunggal, Kec. Depok, Kabupaten Sleman, Yogyakarta 55281

E-mail: djarot_gg@yahoo.com
} 
nal art forms, especially traditional dances in Kebumen Regency in Central Java Province, Indonesia. The supporting object, on the other side, is the role of society in exploring the potency of traditional art and the government policy of Kebumen Regency in its relation to art and culture sector. Analysis and study towards the existence of cultural art in this present research are done by looking from the perspective of linguistics. It means that the linguistic terms in both traditional dances in this study will be discussed and revealed in order to find out the function and meaning of its existence. Thus, this study is specifically directed to two main purposes, the linguistic study and the performing art study.

In addition to this, problems arisen in this study that will be discussed further will be about the origin, the form, the function, and the meaning of terms used to refer to qualities of movement in typical traditional dances from Kebumen regency, Lawet dance and Ebleg dance. The specific aim is to produce an analysis of the existence of traditional cultural art, especially traditional dances, and to produce a critical analysis towards the importance of getting to know the potential of the ownership of traditional art and culture in order to discover local wisdom.

Data used in this study was gathered from field observation, interview, and documentation study related to the popular forms of arts that exist in Kebumen region. The folk dance of Kebumen Regency namely Lawet dance is very typical since it tells about the natural resources of Kebumen regency that are hardly found in other regions, that is the Swift's nest (the nest of Lawet bird). Another Kebumen folk dance that is used as the research subject in this study is Ebleg dance. In Javanese society, the dance is similar to Jathilan dance. It is believed by Kebumen society that the dance is a typical traditional folk dance inherited from the ancestors. Even though the dance also exists in other regions within Central Java province, however, the Ebleg dance performance in Kebumen is very typical since it can reflect the social expressi- on of its society well.

To analyze the dance further from the perspective of linguistics, regarding the terms used to refer to the qualities of movements in both Lawet dance and Ebleg dance, two theories are needed as the ground of discussion. The two theories that are told here are the morphology and semantic theory. According to Poedjosoedarmo, et al. (1970, p. 2), morphology is the branch of linguistics that studies about words and sentence pattern in general. Thus, basically, the morphology analysis concerns with words and all rules with all terms of formation and its amendments. Furthermore, the structural linguistic theory with the analysis of word forms in morphological processes will be able to explain the formation process of terms that are now known as the label or the names to refer to kinds of movements in the dances as well as the sub qualities of movement of Lawet dance that are rooted from the Javanese language.

According to Verhaar (2012, p. 385), semantics is the branch of linguistics that studies meaning. Meaning will be always presented in every grammatical rules or pattern in the form of morphological and syntactical process, so that can be concluded that the branch of linguistics that is used to study about form is morphology. Whereas, semantics is used to understand every name of movement quality in dancing and the sub variations of movement in Lawet dance after the morphological processes in the form of word formation was exist.

Morphological-semantical analysis or study is based on the elements of word formation of Javanese language in the form of a morpheme. Javanese language that can stand alone and can have its own meaning and also its own morpheme may produce new meaning because of a linguistic process namely affixation. Besides, there are also reduplication, acronymic, sound alteration, productivity, frequency, as well as morphemic alterations. Moreover, the word also has the ability that refers to extraordinary elements. This is known as 
a reference. This may give an illustration that in the level of morphology-semantic there is a correlation between the process of word formation with the meaning that is being produced. Besides, there is also a correlation between meanings with references that exist beyond the language itself. The analysis of morphology-semantic is needed to explain the process of word formation and the meaning that is being produced as the name of terms which refer to the names of qualities of the dance movements as well as its dance movement variation and its reference.

The morphological study is used to discuss the data that is being analyzed, specifically one that deals with the morphemes as well as the process of word formation that belongs to the morphological process. According to Poedjosoedarmo (1979, p. 6), the morphological process tells about the word formation of Javanese language. The Javanese language consists of a free and bound morpheme. The example of a free morpheme is like ngulèt or stretching body right after waking up from sleep, dhidhis or sitting while looking for one's own or other's lice, èrèk or walking closer, and giring or getting married, etc. Besides the free morpheme, there is also bound morpheme, the examples of a bound morpheme are prefixed $\mathrm{N}-$, the suffix -an, and also infix -um. The free morpheme in the Javanese language can be formed since it experiences affixation. Besides also experiencing reduplication, vowel change, consonant change, compounding, as well as abbreviating acronym.

After the morphological analysis, discussion will be about aspects of meaning from the morphemes that are being analyzed. In this research, analysis employs semantical lexical analysis that is concerned with lexical meaning (Verhaar, 2012 , p. 388). The field of research dealing with semantical lexical is known as lexicology. The lexical meaning in the linguistic description is usually marked by single quotes. For example, the word noulèt has the meaning of 'stretching body right after waking up from sleep'. The lexical seman- tics in lexicology includes many aspects, among them are: a) meanings and referen$c e, b)$ denotation and connotation, c) extensional analysis and intentional analysis, d) componential analysis, e) meanings and its usage, and f) synonymy, antonymy, homonymy, and hyponymy. This study itself employs lexical semantics that encompasses the first part mentioned, that is meaning and reference.

According to Verhaar (2012, p. 389), the lexical meaning usually refers to the lexical aspect of the nature of the word. For example, the word angklingan has the meaning of 'jumping with one foot', however, besides of this meaning, angklingan also has another nature named as a reference. Reference is the ability of a word to refer to certain things. The referred thing is known as the referent. The referent of the word angklingan is the illustration of the angklingan movement. Thus, it is clear that reference has a clear relation to meaning, so that reference belongs to one of the nature of lexical meaning. The term reference itself brings two different meanings. The first reference belongs to extra lingual reference since the referent comes from the thing outside the language.

This study is inspired by several research results and studies related to the discussed topic. Among the study is one created by the center of law and Indonesian policy studies entitled Kerangka Kajian Hukum untuk Kegiatan Kesenian dan Kebudayaan (PSHK; 2009). It tells about the government policy about culture that is written in legal formalities (law). The study result is considered important since it may become the significant and important source for this present study since it emphasizes on the problems appear that is related to cultural art studies, specifically for the purpose of existence preservation, that can be seen from many aspects of perspective.

The novelty of the present research is in the description and the attempt to reveal in detail about two local culture products, especially from Kebumen regency, the Lawet dance and Ebleg dance. Results of this writing are aiming at revealing the 
relationship and showing the use of traditional art potential in order to strengthen the identity of its owner.

Another aim of this paper writing in academic field is to produce an analysis towards the existence of traditional cultural art, specifically the one which is in the form of traditional folk dances. Besides, the result of this research can be also used as a media or a means to find out the ownership potential of traditional cultural art in order to obtain the local wisdom in this globalization era.

\section{Method}

Based on the aim and theoretical ground of the research, this study employs qualitative method with multidiscipline principle. The further step of the study is analyzing data which is gathered from the written sources as well as field interview.

This study is qualitative research which specifically categorizes as analytical-descriptive. The data that is being gathered, comprises the data of culture-art potential, institutional data in the level of regency government; data in the form of policy product, the process data of the culture-art policy implementation, and the activity data of working program or activity implementation. For this reason, the data can be seeking in the regency government, especially in the institution that is responsible for the culture-art management. Whereas, data about self-potential in the field of cultural art, especially traditional dances from the field, group, or individual artist, and interviews from local society.

Data needed for the research was gathered from documentation study, interview, and observation. Documentation study is done in the related institution; while the interview is done to the institution staff that manages the culture-art management in a local institution, the city council of art, as well as local artists. Observation, therefore, was done in all activities related to the policy of culture-art and its implementation.

\section{Results and Discussion}

The Morpho-Semantics Analysis of Terms Used in Kebumen Regency's Lawet Dance Movement Qualities

The term Lawèt dance consists of two morphemes, the morpheme 'dance' and morpheme 'Lawèt'. It is clear that dance and Lawèt are two kinds of free morphemes since it can stand alone as words. According to Poerwadarminta in the dictionary of Baoesastra Djawa (1939, p.264). Lawèt means 'the swifts'. Swift is a kind of bird who is well-known in Kebumen as Lawèt, which is in other regions are generally known as Walet. The Lawèt dance is a typical dance of Kebumen region. It can be danced by a solo dancer, in a pair, and even in a big mass of dancers and is used as an entertainment dance.

The movements of Lawèt dance are taken from several local styles, like, Banyumas style, Surakarta style, and Balinese style. The movement of Lawèt dance is divided into three motives, there are: the opening, the main, and the closing motives. The opening motive was initiated by the movement known as ngulèt. Then, the main movement consists of seven different movements. The names of the movement, are: angklingan, dhidhis, loncat égot, lenggut maju sérong, ukel nyucuk, lincak nyucuk, and képétan. The last is closing motives which depend on four movement qualities. The names of the qualities are tranjalan, ngasah cucuk, èrèk or giring, and the nest-making movement. Thus, in performance, there are twelve different of dance movements. Then, it is broken down into twentyeight sub-sub qualities, among them are: ngrayung, aburan, ukel mlumah, seblak, ndhaplang, mabur, jinjit, srisig, singgetan, sèlèh, nekuk, ugel-ugel nekuk, tolèhan, napak, nyèngklèh, nyengklèk, kirig, mendhèk, muter, njumbul, ngigel, gèdhèg, manthuk, ngawet, sileman, panggel, gejug, and égotan.

The movement qualities of Lawèt dance belong to two rhythms, the lancaran and dadi rhythms (Sardjoko, 1996, p. 9). The same source mentions that in lancaran rhythm, the lancaran is divided into 
two a) the lancaran rhythm I and b) lancaran rhythm II. The movements in lancaran I rhythm belongs to ngulet. Then, the movement of dadi rhythm is originated from the variation of angklingan, dhidhis, loncat égot, lenggut maju sérong, ukel nyucuk, lincak nyucuk, and kèpètan. The movement of lancaran II rhythm belongs to the variation of tranjalan, ngasah cucuk, èrèk or giring, and the nest-making movement.

In 1993, when Bupati Amin Sudibyo ruled the government, the Lawèt dance received a high response and appreciation so that it is used as an extra subject at school as one of the art teaching material in primary school in Kebumen Regency (Sardjoko, 1996, p. 5). The same source also mentioned that the spreading of Lawèt dance is well-known until the corner part of villages. Even, almost in every event, both in Regency and the lower level, always take Lawèt dance as the entertainment dance. Some of the occasions that used Lawèt dance as the entertainment were the Anniversary of Indonesia's Independence Day, the opening ceremony of art and sport competition, the closing ceremony of art and sport competition, the opening of Quran Recital Competition, the grand opening of Candranimuka stadium, festivals, drama performance, as well as the theme of dance competition for children.

Around 2000, Lawèt dance was no longer used as the Elementary school extra-subject since the rebana art was developing and replaced the position of Lawèt dance. Since that year, the government only gave policies in the form of ownership of Lawèt dance, but never made it into one of extra-subject for students at the school. These evidence showed the journey of Lawèt dance since it was very well-known till now. Currently, only several regions admitted Lawèt dance and used the dance as an entertainment dance, among the regions were: Kecamatan Kebumen, Kecamatan Petanahan, Kecamatan Adimulyo, dan Kecamatan Prembun. It was also used only on certain occasions, like some school performances held in some schools around Kebumen. The schools who were often used the dance as their entertainment are:
Sekolah Menengah Pertama Negeri 1 Kebumen, Sekolah Menengah Pertama Negeri 2 Kebumen, Sekolah Menengah Pertama Negeri 3 Kebumen, Sekolah Menengah Pertama Negeri 7 Kebumen, Sekolah Dasar Negeri 2 Karangsari, Sekolah Dasar Negeri 1 Banyu, Sekolah Dasar Negeri 2 Pejagoan, etc.

The analysis of morphology and semantic process is the core of this present research. Based on the analysis of word and meaning formation process, the form of words and meaning will be known and understood in the scoop of names of movement qualities used in Lawèt dance, as well as reference derived from the term, specifically one contained in the eleven names of Lawèt dance movement along with 28 sub qualities of movement of Lawèt dance in Kebumen Regency. The names of the variation of movement of Lawèt and the sub qualities are further divided into two, the monomorphemic and polymorphemic forms. In the polymorphemic forms, the morphology process is in the form of affixation, compounding as well as morphophonemic change.

Word in the form of monomorphemic are words manifested as monomorphemic morphemes and free morphemes. Here, the words consist of one morpheme only, can stand alone, and has meaning. The examples are in Table 1.

The polymorphemic form of the word is a word manifested as morphememorpheme polymorphemic. The polymorphemic form of words which are found is in the form of affixation, compounding, and morphophonemic change. Here, the affixation form of words can be made and formed from the process of adding affixes. Further, the affixes comprise of adding prefix, suffix, and infix. Based on the gathered data, the affixed word contained in the names of movement qualities of a dance and its sub qualities, comprised of the polymorphemic form originated from the additional prefix N-, combination of prefix $\mathrm{N}$ - and a-, suffix -an, combination of prefix a- and the suffix -an. The examples are in Table 2. 
Table 1. Words manifested as monomorphemic morphemes and free morphem

\begin{tabular}{cc}
\hline Form & Meaning \\
\hline Ngulèt & 'stretching body right after waking up from sleep' \\
Dhidhis & 'sitting while looking for one's own or other's lice' \\
Èrèk atau Giring & 'walking closer atau 'getting married' \\
\hline
\end{tabular}

Table 2. Word contained in the names of movement qualities

\begin{tabular}{ccc}
\hline Form & Afixation Process & Meaning \\
\hline Ngrayung & $\{\mathrm{N}-\}+\{$ rayung $\}$ & 'Pointing and bending fingers' \\
Mabur & $\{\mathrm{N}-\}+\{\mathrm{a}-\}+\{$ bur $\}$ & 'Flying' \\
Angklingan & $\{$ angkling $\}+\{$-an $\}$ & 'Jumping with one leg' \\
Aburan & $\{\mathrm{a}-\}+\{$ bur $\}+\{$-an $\}$ & 'Flying around' \\
\hline
\end{tabular}

Table 3. Compound words existed in the names of movement qualities

\begin{tabular}{|c|c|c|}
\hline Form & Affixation Process & Meaning \\
\hline loncat égot & $\{$ loncat $\}+\{$ égot $\}$ & $\begin{array}{l}\text { 'Jumping followed by the movement of shak- } \\
\text { ing bottom' }\end{array}$ \\
\hline Ukel nyucuk & $\{$ ukel $\}+\{N-\}+\{$ cucuk $\}$ & 'the movement of mematuk to the right and left' \\
\hline Ngasah cucuk & $\{\mathrm{N}-\}+\{$ asah $\}+\{$ cucuk $\}$ & 'the movement of sharpening the beak' \\
\hline Ugel-ugel nekuk & $\begin{array}{l}\{\text { ugel-ugel }\}+\{\mathrm{N}-\} \\
\quad+\{\text { tekuk }\}\end{array}$ & 'the movement of bending the wrist' \\
\hline
\end{tabular}

Table 4. Morpheme along with the allomorphs and the distribution requirement

\begin{tabular}{ccc}
\hline Form & Affixation Process & Meaning \\
\hline Képétan & $\{$ kèpèt $\}+\{-$ an $\}$ & 'shaking tails' \\
Tolèhan & $\{$ tolèh $\}+\{-$ an $\}$ & 'looking to the back side' \\
\hline
\end{tabular}

Referring to the theory by Sudaryanto (1992, p. 51), the data that is being analyzed by the compounding process belongs to part $b$ ), which is the presence of new meaning that closely related to the basic meaning means that the presence of basic meaning happened to be given for the compound words which the root is words. Based on the gathered data, the compound words existed in the names of movement qualities as well as the sub qualities comprise the combination of roots with roots, a combination between roots and affixed words, a combination of affixed words with roots, and combinations of root and root. The examples are in Table 3.

The morphemic change can also be found in the data in the data of morpheme along with the allomorphs and the distribution requirement with its phonology requirement determiner. The examples are

\section{in Table 4.}

The analysis of names of the movement variation of the Lawèt dance explains the lexical and reference meaning of the eleven names of movement variation as well as its 28 sub qualities. The lexical meaning contained in words are followed by its movement reference. There are 11 names of movement in the Lawèt dance and 28 sub qualities of Lawèt dance.

\section{The Semiotic Analysis of Movement Qualities in Kebumen Regency's Ebleg Dance}

Ebleg dance is a typical folk dance from Kebumen with a special property of kuda kepang, a wooden bamboo horse used as the dancing property. This art illustrated the bravery of horsemen army with all the attractions. Usually, in its performance, the dance is followed by the attraction of barongan, penthul and cepet, other kinds 
of traditional arts. Ebleg dance is usually also accompanied by a special music instrument known as bendhe with the typical voice of the traditional singer singing a traditional song. This folk-art performance is usually performed in many celebrations, like, circumcision party, Independence Day celebration, etc. In other regions outside Banyumas and Kebumen regency, the Ebleg dance is usually known as Jaran Kepang, Kuda Lumping, Jathilan, etc.

There are many different versions of the origin of Ebleg dance. It is estimated that the age of this dance is considerably old. This dance is a dance born in the middle of village society. With its simplicity, the dance movement is relatively easier to be followed. Since it is formed naturally in the village, there is no literature that recorded the origin of the dance. However, in the beginning, it is sure that Ebleg dance is a sacred dance that is used in many religious activities. In its development, since the $19^{\text {th }}$ century till after the Independence Day, the dance was started to be added to magic and sacred elements and was used as entertainment as an entertaining dance. In Ebleg dance performance, there are many typical terms known, both in its movement variation types, the music accompaniment, and meanings contained in $E b$ leg dance.

Dance as the valuable and meaningful production of culture can be known as a symbol system (is created by human conventionally and is used orderly). Dance is the expression of human or artist subjectivity and is a significant symbol of the system. It means that dance contains meanings and invites reaction. Therefore, the relationship between signifier and signified is clearer and togetherness is established (Hadi, 2005, p. 24).

In Kebumen, Kuda Lumping is well known as Ebleg. It is a traditional Javanese dance showing soldiers while riding horses. This dance uses horse made of bamboo that is woven and cut then is modified to resemble a horse. This woven horse is given an ornament with paint and cloth in colorful color. The performance of kuda lumping also shows the attraction which shows magical supernatural ability, like, the attraction of chewing glasses material, cutting his own arm with the blade, burning oneself, walking on the broken glass, etc. These attractions are considered as reflecting the supernatural power which in the past was developed in the Javanese kingdom environment and is a non-military aspect that is used to attack the Netherland warrior.

The typical of Kebumen's Ebleg dance, among all is the existence of Barongan, a symbol of a king named Sultan Agung Hanyakrakusuma, who is known as the lion of Mataram. Barongan of Ki Singa Mataram symbolizes Sultan Agung Hanyokrokusumo, one of Mataram's hero. Jaran Kepang (in Black and White color); the symbol of brave horsemen. The color of white symbolizes Turangga/ the Seta Horse, while the black color symbolizes Turangga/ the congregation horse are mythology from ancient Javanese mythology as the symbol of power that has to be united, solid, and balance. While Turangga/ the Seta Horse is a symbol of power that is a kind of pure divinity (soul) while Turangga / the congregation horse is the example of natural power.

Several movement qualities of Ebleg that never can change (the Yudha Cakrakusuma Dance Performance) and its philosophical study is described, as follows:

The formation of Kusuma Mijil which symbolizes the journey of Mataram troops to the battle field.

The offering formation (Puja Cakrakusuma), is expressed in which two hands are bended on the head and lowered down up to the front of eye/nose, headed to the four directions of wind and moved clockwise. In the first obeisance, the Barongan lead in the front (the obeisance movement of barongan is by looking up and nodding to the earth/ prostration. The Caplokan Barongan or kendang, the Javanese traditional music instrument, is used as the obeisance commando of the horsemen troops). Philosophy: The position of obeisance while hands are positioned up on the head symbolizes the worship of the living things 
to the God, while worshiping position to the front of eye and nose symbolizes the attitude of respecting others (wherever the Javanese people are, they are always respecting their God and respecting other human living, as well as the environment). The hands are moving clockwise symbolizes the astronomy of Javanese society that is "Jatingarang" that Naga Dina (the daily rotation), Naga Sasi (the monthly rotation), Naga Taun (the yearly rotation) and Naga Windhu (the moon rotation) lakune mesti manenge (are rotating clockwise).

The formation of marching horse/ Turangga Jejer (The horse soldiers are facing face to face). Barongan takes the up front, middle, and back position of the horsemen soldier. Philosophy: This formation symbolizes the military exercise and formation of Mataram troops lead by Sultan Ageng Hanyakrakusuma. Barongan takes a position in the front, middle, and backside of the horse trips symbolizes a leader who has the spirit of Ing Ngarsa Sung Tuladha, Ing Madya Mangun Karsa, dan Tut Wuri Handayani, which means a leader has to be wise in placing themselves and taking part in a certain condition.

The formation of $S a$ (Javanese traditional and typical font) contains the philosophy: $\mathrm{Sa}$ in Javanese font symbolizes Sultan Agung as the main subject of Ebleg dance.

The formation of Kusuma Lampah symbolizes the journey of Mataram troops to the battle field.

The formation of Margi Ewuh symbolizes the journey of Mataram troops to the battle field which is usually hard and narrow, so that requires them to stand in one line. The troops led by Senopati Margi Ewuh, which the graveyard is currently still well-cared in Panjer.

The cross formation/ Kusuma Sungsang contains the philosophy and illustration of the war strategy had by the Mataram troops in keeping their healthy stamina in the battlefield which is far from the main Kingdom by giving shift schedule to the member of the troops.

The formation of Lumbungan Bad- ranala (The horsemen troops in odd line turning to the right side, while the even number troops are turning to the left side continuing the line of the odd line troops. Lumbungan is done three times with pausing time and the dancers are singing, led by the vice-regent horse number 1 , When doing Lumbungan, Penthul is placed in the middle. This condition symbolized the journey of Mataram troops to the battlefield where they found a granary in Panjer owned by Ki Badranala (Panjer is the name of region in Kebumen in past time), then, the name of the region is used as the center of Logistic as well as the center of attacked strategy quarters under the instruction of a military advisor. Barongan which places in the outer circle symbolizes that King has full trust to his advisor as the reflection of good governance, democratic, and harmonious. The movement of moving and grouping into a small circle is followed by the formation of spacing or stretching the line that is repeated several times symbolizes the maturity or readiness of the war strategy had by the Mataram troops.

The formation of sleeping horse/ Turangga sirep (In the third Lumbangan with Kendang as the commando, forming the formation of a sleeping horse). The White Horse number 1 wakes up and walks around controlling the troops for one cycle. This formation symbolizes the Mataram troops which slowly comes and moves near to the enemy land (VOC). The formation of sleeping horse symbolizes the gerilya strategy had by the Mataram troops where they slowly attack the enemy in the middle of the night. The white horse number 1 wakes up and moves around symbolizes the General of Mataram troops who checks and makes sure that all his subordinates have been up and ready for the attack.

The formation of awakening Horse/ Turangga Lurug (with the commando by Kendang, the troops wakes up together at the same time). The philosophy of the presence of Kendang symbolizes the commando of the General to make the attack. Mendem/ Janturan/ Trance/ Cakraku- 
suman. This movement formation symbolizes the war of the Mataram troops that is full of faith, with the glory of the spirit, and brave in order to fight for their mother land till the end of their life.

\section{Conclusion}

Based on the results and analysis about the morpho-semantics of the terms used to refer to movements of Lawèt dance, it can be concluded that the Lawèt dance is one of typical dance from Kebumen Regency that illustrates the act of the swift bird known as Lawèt. The Lawèt dance belongs to the type of folk creation dance which movements were originally adapted from classical Javanese dance. The Lawèt dance can be categorized as a solo dance, duet dance, as well as mass. The Lawèt dance is created from twelve different dance movements.

The terms used to refer to some movement qualities in Lawèt dances are angklingan, dhidhis, loncat égot, lenggut maju sérong, ukel nyucuk, lincak nyucuk, and képétan. The closing movement, in addition, consists of four qualities of movement, tranjalan, ngasah cucuk, èrèk or giring, and bulding nest. Thus, in one performance, there are 12 different movement qualities. In addition is 28 sub-sub qualities of the movements, namely: ngrayung, aburan, ukel mlumah, seblak, ndhaplang, mabur, jinjit, srisig, singgetan, sèlèh, nekuk, ugel-ugel nekuk, tolèhan, napak, nyèngklèh, nyengklèk, kirig, mendhèk, muter, njumbul, ngigel, gèdhèg, manthuk, ngawet, sileman, panggel, gejug, and égotan.

The names of the movement qualities and the sub qualities are in the form of monomorphemic and polymorphemic. The monomorphemic is a kind of free morpheme. While, the polymorphemic contains affixation and compound sentence. The affixation is prefix $\mathrm{N}$-, combination of prefix N- and suffix -an, suffix -an, and combination of prefix a- suffix -an. The aspect of meaning on qualities of movement contained in Lawèt dance comprises of lexical meaning that refers to reference of the Lawèt dance.
The names of the sub variation are ngulèt, angklingan, dhidhis, loncat égot, lenggut maju sérong, ukel nyucuk, lincak nyucuk, képétan, tranjalan, ngasah cucuk, èrèk or giring, ngrayung, aburan, ukel mlumah, seblak, ndhaplang, mabur, jinjit, srisig, singgetan, sèlèh, nekuk, ugel-ugel nekuk, tolèhan, napak, nyèngklèh, nyengklèk, kirig, mendhèk, muter, njumbul, ngigel, gèdhèg, manthuk, ngawet, sileman, panggel, gejug, and égotan.

Furthermore, the Ebleg dance belongs to the traditional dance that is originated from Kebumen Regency. This dance is very popular among the society in Kebumen Regency, especially in the northern part of Kebumen. The popularity of this dance is proven by the numbers of Ebleg dancers in this region. This dance has typical characteristics and unique in every performance, among them are the magical element or trance, as well as its music and songs accompanying the performance. It also has a unique costume.

Based on the condition described above, therefore, it appears clearly that the potential of local cultural art still needs to be explored from various resources and several approaches as explorative activity needs to be done to record the National Culture resources.

\section{References}

Djawanai, Stephanus.(2011). "Kemanusiaan Sebagai Pemandu dan Penjaga Kehidupan" Disampaikan dalam Fokus Group Discussion dengan Majelis Permusyawaratan Rakyat RI. Yogyakarta: Fakultas Ilmu Budaya UGM.

Geertz, Clifford. (1973). The interpretation of cultures. New York: Basic Books.

Herusatoto, Budiono. (1984). Simbolisme Budaya Jawa. Yogyakarta: P.T. Hanindita.

Koentjaraningrat. (1983). Tari dan Kesusastraan di Jawa. Yogyakarta: C.V. Karyono.

Koencaraningrat. (1986). Manusia dan Kebudayaan Indonesia. Yogyakarta: Gadjah Mada Press. 
Kridalaksana, Harimurti. (2008). Kamus Linguistik. Jakarta: P.T. Gramedia Pustaka Utama.

Lindsay, Jennifer. (1995). Cultural Policy and the Performing Arts in Southeast Asia. Bijdragen tot de Taal-, Landen Volkenkunde, Deel (151), 656-671.

Poerwadarminta, W.J.S. (1939). Baoesastra Djawa. Groningen Batavia: J.B. Wolters Uitgevers Maatschappij.

PSHK; , T. P. (2009) Kerangka Hukum Untuk Kegiatan Kesenian dan Kebudayaan (Gambaran Umum) - Pendahuluan. Available at: http://s. kabeh-ngerti.com/pravo/682/index.html?page $=2$ (Accessed: 25 July 2016).

Sardjoko. (1996). Sekilas tentang Tari Lawet: Mulok Sekolah Dasar. Kebumen: Penilik Kebudayaan Kantor Departemen Pendidikan dan Kebudayaan Kecamatan Alian.

Soebadio, Haryati. (1985). Cultural Policy in Indonesia. Paris, Perancis: UNESCO.
Soedarsono, R.M.. tt. Tari-tarian Indonesia I. Jakarta: Proyek Pengembangan Media Kebudayaan, Direktorat Jendral Kebudayaan, Departemen Pendidikan dan Kebudayaan.

Sutton, R. A. (1995). Performing Arts and Cultural Politics in South Sulawesi. Bijdragen tot de Taal-, Land-en Volkenkunde, Deel 151, 171(4), 672-699

Tim Penyusun. 1995. Kebumen Selayang Pandang Edisi Pertama. Kebumen: Bappeda Kabupaten Dati II Kebumen.

Tim Penyusun. (2011). Kebumen dalam Angka 2011. Kebumen: Bappeda dan BPS Kabupaten Kebumen.

Tim Penyusun. (2013). Data Kebudayaan Kabupaten Kebumen. Kebumen: Dinas Pariwisata dan Kebudayaan Kabupaten Kebumen.

Verhaar, J.W.M., (2012). Asas-Asas Linguistik Umum. Yogyakarta: Gadjah Mada University Press. 